\title{
Differential regulation of SAP8 and SAP9, which encode two new members of the secreted aspartic proteinase family in Candida albicans
}

\author{
Michel Monod, ${ }^{1}$ Bernhard Hube, ${ }^{2}$ Daniela Hess ${ }^{2}$ \\ and Dominique Sanglard ${ }^{3}$
}

1,3 Service de Dermatologie (DHURDV), Laboratoire de Mycologie', and Institut de Microbiologie ${ }^{3}$, Centre Hospitalier Universitaire Vaudois, 1011 Lausanne, Switzerland

2 Institut für Allgemeine Botanik, Angewandte Molekularbiologie III, Universităt Hamburg, Hamburg, Germany

\author{
Author for correspondence: Michel Monod. Tel: +41 21314 0376. Fax: +41213140378. \\ e-mail: Michel.Monod@chuv.hospvd.ch
}

\begin{abstract}
Secreted aspartic proteinases (Saps) contribute to the virulence of Candida albicans in systemic animal models of infection. Seven genes encoding Saps (SAP1-SAP7) have been identified to date but evidence suggested the existence of additional SAP genes. The screening of a C. albicans $\lambda E M B L 3$ genomic library for the presence of other SAP genes was undertaken. Two new genes, SAP8 and SAP9, were isolated. The $\mathrm{N}$-terminal amino acid sequence deduced from SAP8 downstream of a Kex2p-like cleavage site corresponds to the $\mathrm{N}$-terminal amino acid sequence of the $41 \mathrm{kDa}$ Sap isolated and characterized previously. SAP8 MRNA was expressed preferentially in yeasts at $25^{\circ} \mathrm{C}$ after 6 and $9 \mathrm{~h}$ growth in BSA-containing medium. SAP9 encodes an aspartic proteinase with a Kex2p-like cleavage site and contains a putative glycophosphatidylinositol-anchor signal at the C-terminus. Although the SAP9 gene product has not yet been isolated from cultures of C. albicans, transcripts of SAP9 were observed preferentially in later growth phases when SAP8 expression had decreased.
\end{abstract}

Keywords: Candida albicans, secreted aspartic proteinases, gene family

\section{INTRODUCTION}

The opportunistic pathogen Candida albicans secretes aspartic proteinases (Saps), which raises a particular interest because of their role as virulence factors (Hube et al., 1997b; Sanglard et al., 1997). Seven gene sequences, $S A P 1-S A P 7$, encoding secreted proteinases are known in C. albicans (Monod et al., 1994). Following RNA hybridization experiments, these genes have been shown to be differentially regulated in vivo (Hube et al., 1994; White \& Agabian, 1995). When BSA is the sole nitrogen source in the medium, C. albicans secretes one dominant aspartic proteinase, Sap2p. Two other isoenzymes, Sap1p and Sap3p, have been recovered from a particular C. albicans strain, WO-1, which switches from a white to an opaque form at a frequency of $10^{-2}$ to $10^{-4}$ per cell cycle. Opaque cells produce Sap1p, Sap2p and Sap3p, while white cells of the same strain

Abbreviations: GPI, glycophosphatidylinositol; Sap, secreted aspartic proteinase.

The GenBank accession numbers for the sequences reported in this paper are AF043330 and AF043331. secrete Sap2p only (Morrow et al., 1992; White et al., 1993). However, a fourth Sap protein with an Nterminal amino acid sequence not identical to any $\mathrm{N}$ terminal sequence of mature forms of Sap1p-Sap7p was isolated by Morrison et al. (1993) from the supernatant of C. albicans stationary phase cultures in BSA medium at $25^{\circ} \mathrm{C}$. This finding supported the existence in $C$. albicans of $S A P$ genes other than those previously reported. The screening of a $C$. albicans $\lambda E M B L 3$ genomic library for the presence of other $S A P$ genes was undertaken and we report here the cloning, sequencing and expression pattern of two additional genes, one of which, SAP8, encodes the Sap previously isolated by Morrison et al. (1993).

\section{METHODS}

Organisms and plasmids. Escherichia coli LE392 was used as a host strain for propagation of bacteriophages. The $C$. albicans genomic library was previously constructed in AEMBL3 (Monod et al., 1994). All plasmid subcloning experiments were performed in E. coli strain DH $5 \alpha$ using the plasmid pMTL21 (Chambers et al., 1988). E. coli DH5 $\alpha$ was 
transformed using competent cells with standard protocols (Sambrook et al., 1989).

Since the SAP8 gene product was originally detected in C. albicans strain DSM 6659 (Morrison et al., 1993), this strain (kindly provided by R. Rüchel, University of Göttingen, Germany) was used for gene expression studies. Strain WO-1 (kindly provided by D. Soll, University of Iowa, USA) was used for expression studies during phenotypic switching.

Culture media and growth conditions. C. albicans strains were stored on YPG $(1 \%, w / v$, yeast extract; $2 \%, w / v$, peptone; $2 \%, \mathrm{w} / \mathrm{v}$, glucose) agar plates at $4{ }^{\circ} \mathrm{C}$. For Northern blot analysis, the following liquid media were used: $1.17 \%$ $(\mathrm{w} / \mathrm{v})$ Yeast Carbon Base (Difco), $1 \%(\mathrm{w} / \mathrm{v})$ glucose, $0.5 \%$ (w/v) BSA (BSA medium; Sigma); modified Lee's medium (Morrow et al., 1992). Each $50 \mathrm{ml}$ culture was inoculated with $1 \mathrm{ml}$ of a C. albicans overnight culture grown in the same medium. Cultures were shaken in an orbital incubator at either 25 or $37^{\circ} \mathrm{C}$. Growth was monitored by measuring the $\mathrm{OD}_{600}$ (Beckman DV.65 spectrophotometer) and cell samples were harvested at different times for $2 \mathrm{~d}$. White-opaque switching and the stability of both growth forms of strain WO-1 were checked microscopically.

Screening of a C. albicans genomic library. Recombinant bacteriophage plaques of the genomic library were immobilized on nylon membranes (Zeta-Probe; Bio-Rad). The membranes were prehybridized for $1 \mathrm{~h}$ at $50^{\circ} \mathrm{C}$ in a solution containing $5 \times$ SSC, $7 \%(\mathrm{w} / \mathrm{v})$ SDS, $10 \times$ Denhardt's solution, $20 \mathrm{mM} \mathrm{NaH} \mathrm{PO}_{4}(\mathrm{pH} 7.0)$ and $100 \mu \mathrm{g}$ denatured salmon sperm DNA ml ${ }^{-1}$. Hybridization was performed with $\gamma^{-32} \mathrm{P}$ labelled oligonucleotides at $50^{\circ} \mathrm{C}$ for $24 \mathrm{~h}$ in the same buffer. The membranes were exposed to X-ray films after two washes in $3 \times \mathrm{SSC}, 5 \%(\mathrm{w} / \mathrm{v}) \mathrm{SDS}, 25 \mathrm{mM} \mathrm{NaH} \mathrm{PO}_{4}(\mathrm{pH} 7.0)$ at $40{ }^{\circ} \mathrm{C}$. Oligonucleotides were labelled with polynucleotide kinase as described by Sambrook et al. (1989) in the presence of $\left[\gamma^{32} \mathrm{P}\right]$ ATP (Amersham). Positive plaques were purified and the DNA was isolated as described by Grossberger (1987). Agarose gel electrophoresis of restricted recombinant $\lambda E M B L 3$ DNA and Southern blotting were performed according to standard protocols (Sambrook et al., 1989).

DNA sequencing. DNA subcloned into plasmid pMTL21 (Chambers et al., 1988) was sequenced using a Licor model automatic sequencer.

RNA isolation and Northern blotting. Total RNA from $C$. albicans was prepared as described by Hube et al. (1994). Briefly, cells were extracted with glass beads, extraction buffer $(0.1 \mathrm{M}$ Tris/HCl, pH 7.5; $0.1 \mathrm{M} \mathrm{LiCl} ; 0.01 \mathrm{M}$ DTT $), 1 \%$ (w/v) SDS and phenol/chloroform. The aqueous phase was removed and extracted twice in phenol/chloroform and the RNA was then precipitated with ethanol.

RNA samples were separated on formaldehyde agarose gels as described by Hube et al. (1994). Fractionated RNA was blotted (VacuGene; Pharmacia) onto nylon membranes (Hybond-N; Amersham) in $10 \times \mathrm{SSC}(\mathrm{pH} 7.0$ ) for $8 \mathrm{~h}$. After transfer of RNA, the membrane was rinsed with $6 \times$ SSC, airdried and photographed using a UV transilluminator to determine the position of the $28 \mathrm{~S}$ and $18 \mathrm{~S}$ rRNA bands. The RNA was cross-linked to the membrane by baking for $2 \mathrm{~h}$ at $80^{\circ} \mathrm{C}$.

PCR was used to prepare hybridization probes for Southern and Northern blotting. Fragments of $1215 \mathrm{bp}$ and $1632 \mathrm{bp}$ in the ORFs of SAPB and SAP9, respectively, were amplified. Pairs of primers were: $5^{\prime}$-GTTGACACAGGTTCTTCTG-3' and $5^{\prime}$-TCAGCCTTCTATGCCTTTTG-3' for SAP8; $5^{\prime}$ GTGCCACCAAATGAGAC- $3^{\prime}$ and $5^{\prime}$-CCTCTATTGTGTGTAAATG-3' for SAP9. DNA fragments were purified by using the Prep-a-Gene kit (Bio-Rad) and labelled with $\left[\alpha{ }^{32}\right.$ P]dCTP (Amersham) by random priming (Boehringer). To test the specificity of SAP probes, Southern blots of C. albicans genomic DNA digested with EcoRI were hybridized to each probe under high stringency conditions (Hube et al., 1994). Single bands were detected with both SAP8 and SAP9 probes. Northern blots were then hybridized under the same conditions (Hube et al., 1994).

\section{RESULTS}

\section{Cloning of two new members of the C. albicans SAP gene family}

The overall number of SAP genes in C. albicans was tentatively estimated by Southern blot analysis of EcoRIdigested genomic DNA of different C. albicans strains and hybridization with SAP1-SAP7 probes encoding the $\mathrm{N}$-terminal aspartyl domain of the Sap active site (Monod et al., 1994). Eight distinct bands, designated A1-A8, were identified. Five of these bands, A1, A3, A5, A6 and A8, corresponded to each of the EcoRI fragments characteristic of SAP2, SAP7, SAP1, SAP5 and SAP3, respectively. The band $A 7$ corresponded to unresolved $1.2 \mathrm{~kb}$ fragments characteristic of SAP4 and SAP6. Two bands, A2 and A4, for two fragments of 6.0 and $3.7 \mathrm{~kb}$, respectively, corresponded to none of the previously isolated SAP1-SAP7. Furthermore, both fragments hybridized with the oligonucleotide probe $5^{\prime}$-GTT ATT GTT GA(T/C) ACT GG(A/G) TCT TCT GAT TT(A/G) TGG-3' designed as a consensus of the nucleotide sequence encoding the $\mathrm{N}$-terminal aspartyl domain $\mathrm{V}(\mathrm{V} / \mathrm{I} / \mathrm{M})(\mathrm{I} / \mathrm{L} / \mathrm{V}) \mathrm{DTGSSD}(\mathrm{L} / \mathrm{F}) \mathrm{W}$ of the catalytic site of the Sap isoenzymes. Therefore, the existence of two other genes encoding aspartic proteinases in $C$. albicans was inferred in addition to SAP1-SAP7. A further screening of a $C$. albicans $\lambda E M B L 3$ genomic library, from which SAP1-SAP7 were isolated (Monod et al., 1994), was performed using the oligonucleotide probe and low stringency conditions of hybridization. Among $10^{4}$ individual recombinant bacteriophage plaques, corresponding to $10 \mathrm{C}$. albicans genome equivalents, all hybridizing clones (100 in total) were purified. The DNA obtained from these clones was restricted with EcoRI, blotted onto membranes and hybridized with the selecting oligonucleotide probe. The clones containing a hybridizing EcoRI fragment corresponding

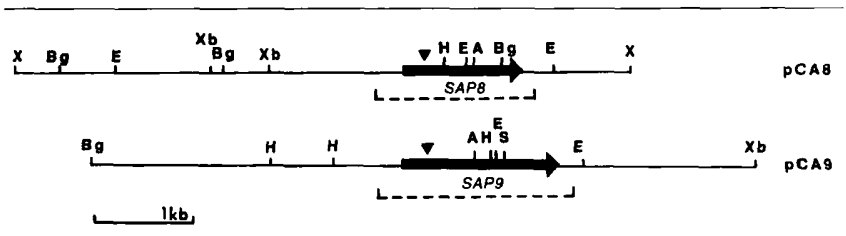

Fig. 1. Restriction maps of inserts of the plasmids containing the C. albicans SAP8 and SAP9 genes. The SAP ORFs are represented by solid arrows. The $\mathrm{N}$-terminal domains of the catalytic site of the enzymes are indicated by solid triangles. The GenBank accession numbers of the sequenced regions of PCA 8 and pCA9 represented by a dashed line are AF043330 and AF043331, respectively. A, Asp718; Bg, Bg/ll; E, ECORI; H, HindIII; S, Sall; $X$, Xhol; $X b, X$ bal. 


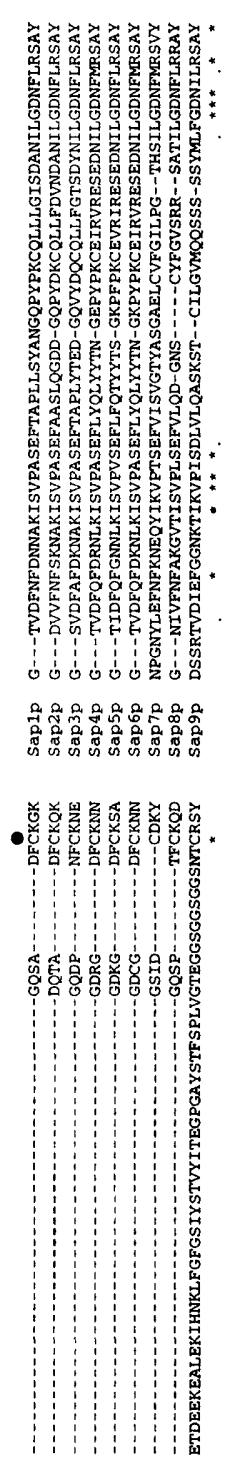

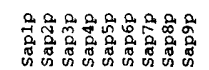

8 .

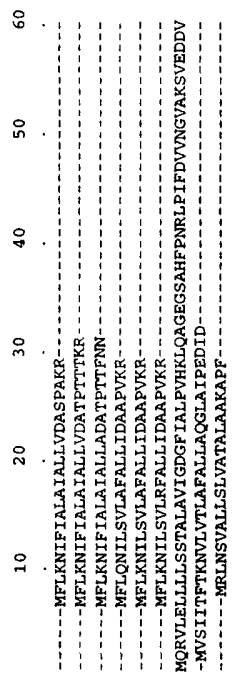

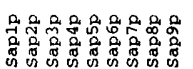
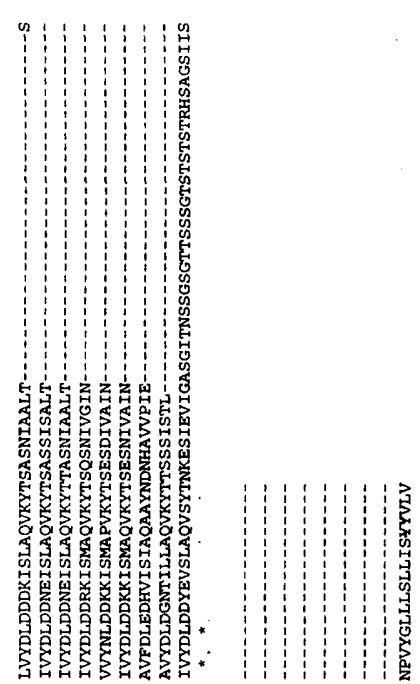

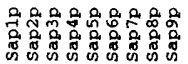

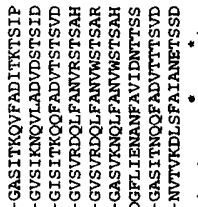

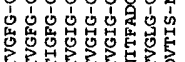

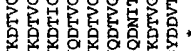

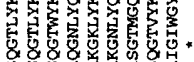

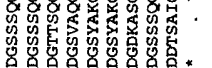

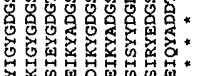

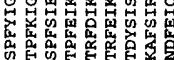

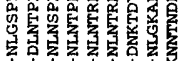

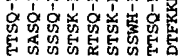

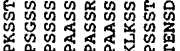

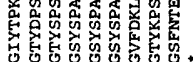

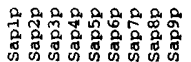

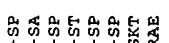

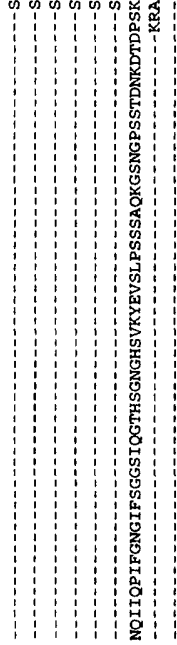

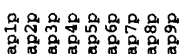

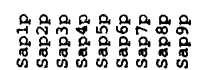

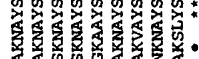

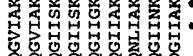

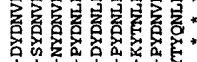

o

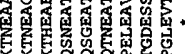

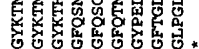

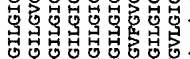

$888 \div 25$

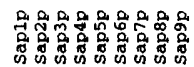

들ำ

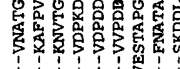

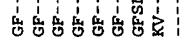

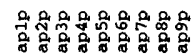

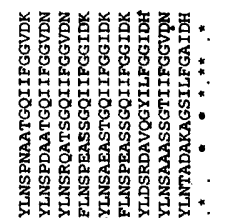

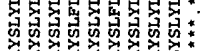

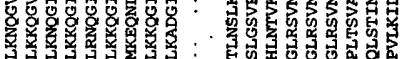

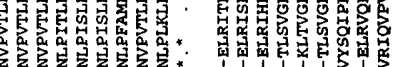

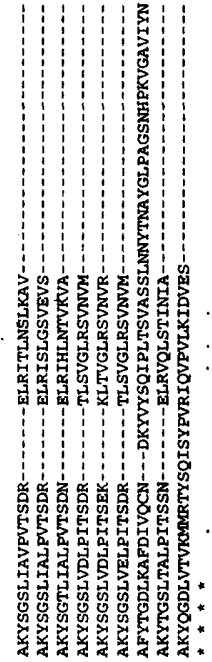

-

ำ

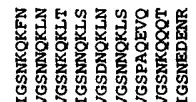
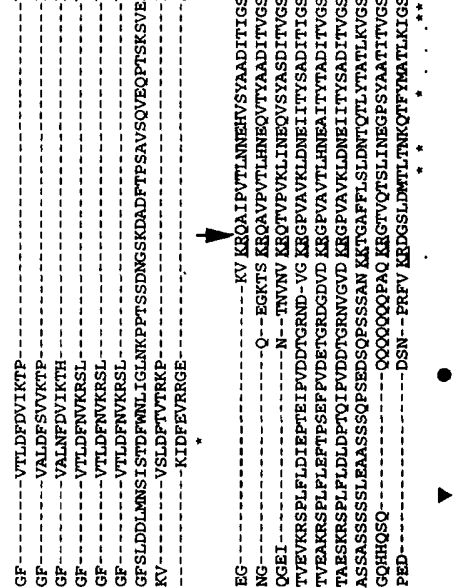

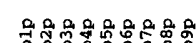

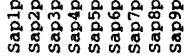

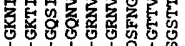

站

- ents.

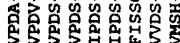

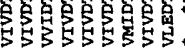

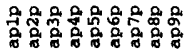

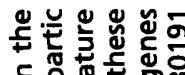

등

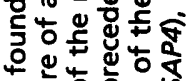

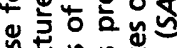

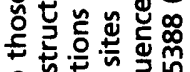

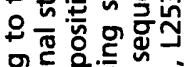

은음

은

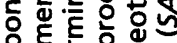

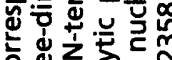

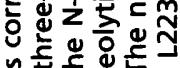

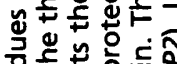

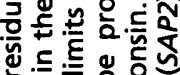

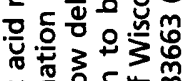

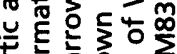

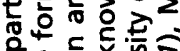

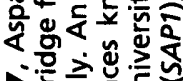

塎

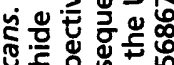

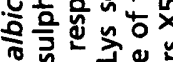

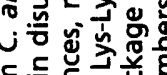

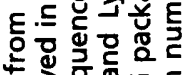

응 웡

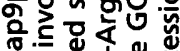

人 든

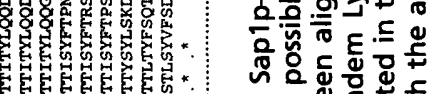

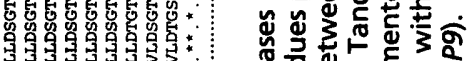

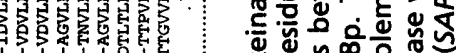

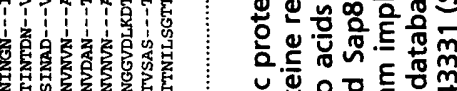

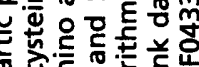

哭诘

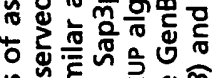

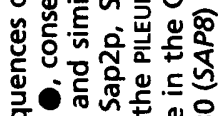

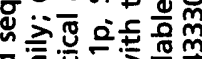

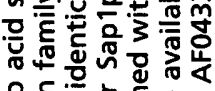

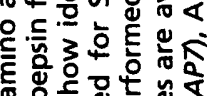

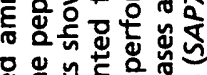

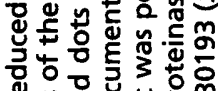

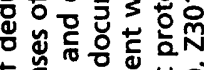

of

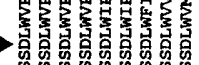

Oे 
Table 1. Pairwise comparisons of Sap proteins from C. albicans

The percentage similarity (top right-hand corner) and percentage divergence (bottom left-hand corner) values were obtained using the program CLUSTAL (Higgins $\&$ Sharp, 1989) with a PAM 250-residue weight table.

\begin{tabular}{|c|c|c|c|c|c|c|c|c|c|}
\hline & Saplp & Sap2p & Sap3p & Sap4p & Sap5p & Sap6p & Sap 7p & Sap8p & Sap9p \\
\hline Sap1p & $* * *$ & $67 \cdot 1$ & $67 \cdot 6$ & $57 \cdot 4$ & $55 \cdot 4$ & $56 \cdot 6$ & $20 \cdot 4$ & $50 \cdot 0$ & $28 \cdot 1$ \\
\hline Sap $2 p$ & $26 \cdot 7$ & $* * *$ & $69 \cdot 8$ & $55 \cdot 0$ & 52.5 & $55 \cdot 0$ & $27 \cdot 4$ & $50 \cdot 0$ & $28 \cdot 6$ \\
\hline Sap3p & $29 \cdot 0$ & $27 \cdot 5$ & $* * *+$ & $53 \cdot 0$ & $49 \cdot 2$ & $52 \cdot 3$ & $26 \cdot 9$ & 50.5 & $22 \cdot 1$ \\
\hline Sap4p & $40 \cdot 8$ & $42 \cdot 4$ & $43 \cdot 7$ & $* * *$ & $77 \cdot 2$ & 89.9 & $26 \cdot 4$ & $43 \cdot 4$ & 29.5 \\
\hline Sap5p & $42 \cdot 6$ & $45 \cdot 2$ & $47 \cdot 5$ & $22 \cdot 1$ & $* * * *$ & $80 \cdot 4$ & $26 \cdot 1$ & $41 \cdot 2$ & $26 \cdot 8$ \\
\hline Sap6p & $41 \cdot 0$ & $42 \cdot 1$ & $44 \cdot 2$ & $9 \cdot 4$ & $19 \cdot 6$ & $* * * *$ & $27 \cdot 3$ & $42 \cdot 4$ & $26 \cdot 3$ \\
\hline Sap $7 p$ & $74 \cdot 8$ & 75.9 & $75 \cdot 7$ & $76 \cdot 6$ & $75 \cdot 9$ & $76 \cdot 4$ & $* * *$ & $25 \cdot 3$ & $17 \cdot 1$ \\
\hline Sap8p & $48 \cdot 5$ & $46 \cdot 6$ & $45 \cdot 8$ & $54 \cdot 6$ & $56 \cdot 2$ & 55.0 & $74 \cdot 8$ & $* * * *$ & $26 \cdot 3$ \\
\hline Sap9p & $66 \cdot 4$ & $67 \cdot 2$ & $67 \cdot 8$ & $65 \cdot 8$ & $68 \cdot 2$ & 66.7 & $76 \cdot 8$ & $68 \cdot 6$ & $* * * *$ \\
\hline
\end{tabular}

to $S A P 1-S A P 7$ were eliminated. Four groups of clones containing $6.0,3.7,3.2$ and $2.4 \mathrm{~kb}$ EcoRI fragments which did not correspond to any of SAP1-SAP7 were retained and further analysed. The 6.0 and $3.7 \mathrm{~kb}$ EcoRI fragments corresponded to the bands $\mathrm{A} 2$ and $\mathrm{A} 4$. The four EcoRI fragments were subcloned into pMTL21 (Chambers et al., 1988) and partial sequencing of their extremities revealed that the 6.0 and $3.7 \mathrm{~kb}$ fragments contained parts of new aspartic proteinase genes encoding the $\mathrm{N}$-terminal aspartyl domain of the protein. Sequencing of the 3.2 and $2.4 \mathrm{~kb}$ EcoRI fragments, which show only a weak signal with the oligonucleotide probe, revealed no sequence similarities with any of the $S A P$ genes and were not studied further. The genes corresponding to the 3.7 and $6.0 \mathrm{~kb} \mathrm{EcoRI} \mathrm{fragments}$ were called SAP8 and SAP9, respectively. Further restriction analysis of bacteriophage DNA permitted the identification of fragments of about $6 \mathrm{~kb}$ that contained the entire new SAP genes. These fragments were subcloned into $\mathrm{pMTL} 21$, generating the plasmids pCA8 and pCA9 for which the map of the inserts is shown in Fig. 1. SAP8 and SAP9 are localized on chromosome 3 (S. Scherer, personal communication; data available at http://alces.med.umn.edu/bin/genelist?genes).

\section{Amino acid sequences deduced from SAP8 and SAP9}

SAP8 and SAP9 contain ORFs of 1215 and 1632 bp encoding proteins of 405 and 544 amino acids, respectively. The Sap8p and Sap9p proteins showed similarity with other aspartic proteinases, in particular within the regions which contained the two reactive aspartic acid residues of the active site for these enzymes. The amino acid sequences of Sap8p and Sap9p, which were aligned with those of Sap1p-Sap7p, suggested the existence of a signal peptide with putative signal peptidase cleavage sites (von Heijne, 1986) and the existence of a prosequence with pairs of Lys-Arg residues which are known to be proteolytic processing sites for the proconvertase Kex2p in Saccharomyces cerevisiae (Fig. 2). The Sap8p and Sap9p protein molecules generated by cleavage at the Kex $2 \mathrm{p}$-like cleavage site

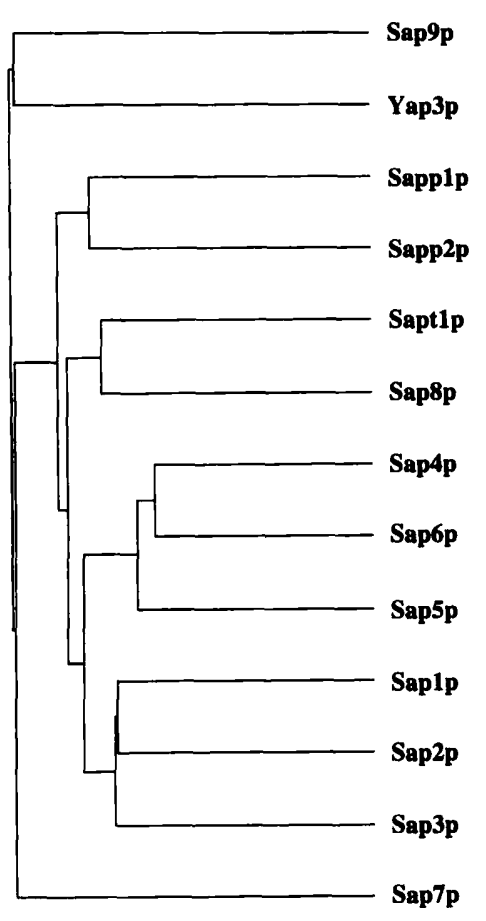

Fig. 3. Dendrogram of the currently known Candida Saps and the GPI-anchored proteinase Yap3p of S. cerevisiae. Sapp and Sapt denote the proteinases secreted by Candida parapsilosis and C. tropicalis, respectively. The branch lengths are proportional to the similarity between amino acid sequences. The dendrogram was created by the PILEUP program by the unweighted pair-group method using arithmetic means (GCG package, University of Wisconsin).

have a calculated molecular mass of 35 and $52 \mathrm{kDa}$, respectively. Pairwise comparisons for all members of the Sap family in C. albicans are shown in Table 1. The dendrogram deduced from the alignments of different Candida Saps and the aspartic proteinase Yap3p of $S$. cerevisiae shows that Sap8p and Sap9p belong to branches distinct from the Sap1p, Sap2p and Sap3p group, and from the Sap4p, Sap5p and Sap6p group (Fig. 3). Sap8 is clustered with Sapt $1 p$, the aspartic pro- 


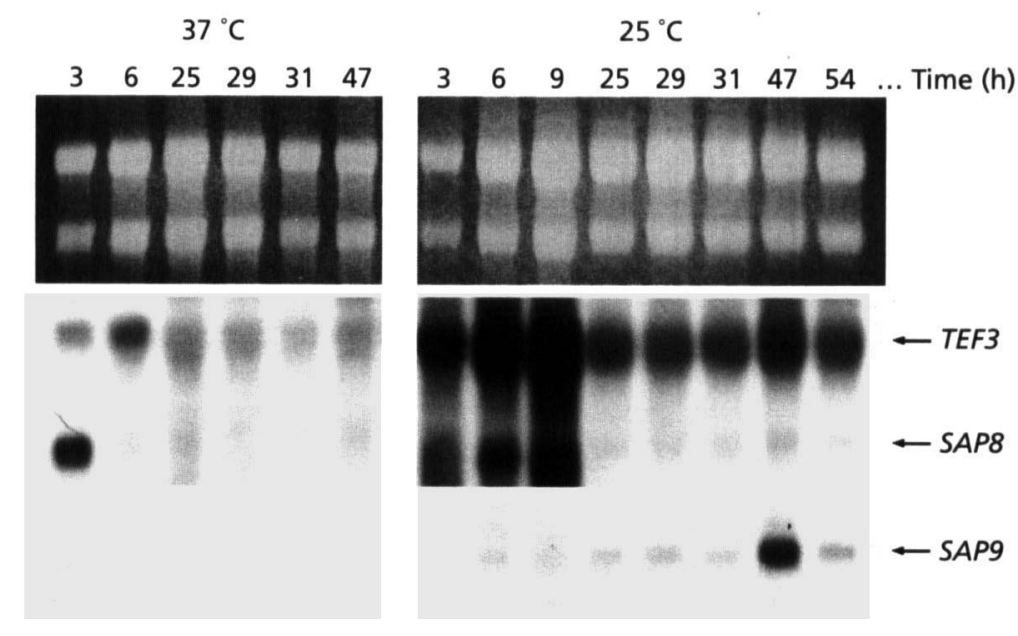

Fig. 4. Northern blot analysis of SAP8 and SAP9 expression. C. albicans DSM 6659 was grown in BSA medium at 37 and $25^{\circ} \mathrm{C}$, where the stationary phase starts from 24 and $36 \mathrm{~h}$, respectively. Six and eight samples, respectively, were taken over $3 d$ during batch growth at the times indicated, and Northern blots of the prepared RNA were hybridized to radiolabelled PCR fragments of SAPB and SAP9 as described in Methods. Approximately equal amounts of total RNA were loaded in each lane of the Northern blots and allowed assessment of the mRNA levels of SAPB and SAP9. In addition, the TEF3 mRNA (Colthurst et al., 1992) was also probed as a positive but non-quantitative control. TEF 3 expression is down-regulated in the stationary phase during batch growth (Swoboda et al., 1994). Probed TEF3 mRNA and ethidium-bromide-stained IRNAs are shown for all samples.

teinase secreted by Candida tropicalis in BSA medium (Togni et al., 1991), and Sap9p is clustered with Yap3p.

\section{Expression of SAP8}

The N-terminal amino acid sequence deduced from SAP8 downstream of the Kex2p-like cleavage site corresponds to the $\mathrm{N}$-terminal sequence of the mature $41 \mathrm{kDa}$ Sap isolated and characterized by Morrison et al. (1993). This Sap was detected during growth of $C$. albicans DSM 6659 in BSA medium at $25^{\circ} \mathrm{C}$. To investigate the expression pattern of SAP8, we isolated total RNA from strain DSM 6659 grown under these conditions and probed for SAP8 mRNA. SAP8 was expressed preferentially during the early exponential phase of growth of the yeast cells, i.e. after 6 and $9 \mathrm{~h}$ growth at $25^{\circ} \mathrm{C}$ and after $3 \mathrm{~h}$ at $37^{\circ} \mathrm{C}$ in BSA medium (Hube et al., 1994). However, SAP8 was expressed at lower levels at $37^{\circ} \mathrm{C}$ than at $25^{\circ} \mathrm{C}$ (Fig. 4). Interestingly, SAP8 mRNA levels detected in the early exponential phase at $37^{\circ} \mathrm{C}$ disappeared within $3 \mathrm{~h}$ (Fig. 4). Such a sharp regulation was also found for the regulation of SAP2 expression (Hube et al., 1994). Since we observed $S A P 2$ and SAP3 expression under the same conditions (Hube et al., 1994), it can be concluded that these three proteinase genes may be expressed by C. albicans DSM 6659 under similar physiological conditions. The higher level of SAP8 mRNA during growth at $25^{\circ} \mathrm{C}$ may explain the earlier observed temperature-dependent sensitivity effect of proteinase production during growth of C. albicans DSM 6659 in BSA medium at $25^{\circ} \mathrm{C}$ (Crandall \& Edwards, 1987).

The temperature dependence of SAP8 expression was also tested in the switching strain WO-1 (Soll, 1992). Several genes, including $S A P$ genes, are regulated during the white-opaque switching of WO-1 (Morrow et al., 1992 , 1994). RNA isolated from both white and opaque forms of WO-1 grown in BSA medium at 25 and $37^{\circ} \mathrm{C}$ was tested for $S A P 8$ transcripts. The SAP8 mRNA was found to be abundant in opaque cells at $25^{\circ} \mathrm{C}$, but poorly expressed in the white form at $37^{\circ} \mathrm{C}$ (not shown). Thus the opaque form was able to express at least four different proteinase genes (SAP1, SAP2, SAP3 and SAP8) under the same conditions, all of which together may be responsible for the higher extracellular proteolytic activity of this switching form (Hube et al., 1997a).

\section{Expression of SAP9}

To investigate the expression of $S A P 9$, Northern blots which showed SAP1-SAP3 and SAP8 signals were stripped and reprobed with $S A P 9$. A low level of $S A P 9$ transcripts was found in most RNA samples (not shown). However, a strong signal was observed at $25^{\circ} \mathrm{C}$ after $45 \mathrm{~h}$ corresponding to stationary phase of growth in BSA medium (Fig. 4) (Hube et al., 1994). This expression is different from most identified SAP genes and may indicate a divergent role for this gene.

\section{DISCUSSION}

Several points support the conclusion that SAP8 encodes the $41 \mathrm{kDa}$ protein detected by Morrison et al. (1993). (i) The N-terminal amino acid sequence deduced from $S A P 8$ downstream of the Kex2p-like cleavage site corresponds to the $\mathrm{N}$-terminal amino acid sequence of the mature $41 \mathrm{kDa}$ form of this protein. (ii) The SAP8 mRNA and the $41 \mathrm{kDa}$ protein are both expressed in BSA-containing media at $25^{\circ} \mathrm{C}$. These are growth conditions corresponding to those in which the $41 \mathrm{kDa}$ protein was produced. One possible reason for the difference between the observed $(41 \mathrm{kDa})$ and the predicted $(36 \mathrm{kDa})$ molecular mass of Sap8p is that the value of $41 \mathrm{kDa}$ reported by Morrison et al. (1993) was an overestimate. Indeed, Sap2p was described at the same time as a $48-49 \mathrm{kDa}$ protein whereas its apparent molecular mass on SDS-PAGE is $40 \mathrm{kDa}$ (de Viragh et al., 1993). Since SAP8 is expressed preferentially at 


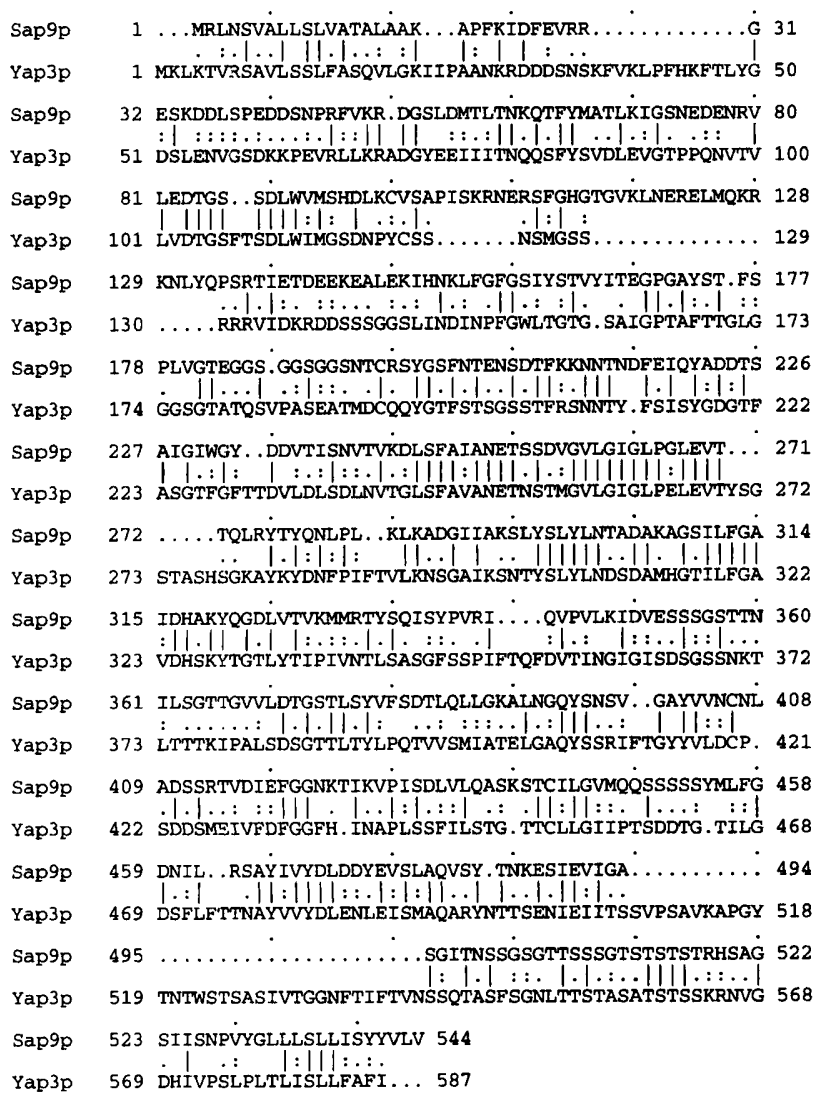

Fig. 5. Comparison of the S. cerevisiae YAP3 and C. albicans SAP9 gene products. The identity and similarity between Yap3p and Sap9p are 37.7 and $58.9 \%$, respectively. The comparison was performed with the program GAP implemented in the GCG package of the University of Wisconsin. Bars indicate identity between amino acids, whereas colons and stops represent high and low conservation between amino acids of each sequence.

$25^{\circ} \mathrm{C}$, it seems unlikely that this gene plays an important role during infection at the body temperature of the host. However, transcripts of $S A P 8$ have recently been found in models of oral candidosis (M. Schaller, W. Schaefer, H. C. Korting \& B. Hube, unpublished results). It may therefore be possible that other inducing factors are important for SAP8 expression during host infection.

The putative $\mathrm{N}$-terminal amino acid sequence of the mature Sap9p does not correspond to any previously isolated $C$. albicans Sap proteins. Interestingly, the deduced translation product of SAP9 has a C-terminal extremity that is 51 amino acids longer than that of all other Saps (Fig. 2). This C-terminal extremity is serine/threonine-rich and can be aligned to the Cterminal extremity of the aspartic proteinase Yap3p of S. cerevisiae (Fig. 5), which was shown to be a glycophosphatidylinositol (GPI)-anchored protein (Ash et al., 1995). The Sap9p amino acid sequence GASG at positions 493-496 is also identical to the consensus sequence of the site of cleavage and attachment of GPIanchored proteins (Gerber et al., 1992). Therefore, it is probable that Sap9p is a GPI-anchored aspartic proteinase. Moreover, Sap9p is more related to Yap3p than to any other Candida Saps (Fig. 3). Because GPIanchored proteins follow the usual secretory pathway, we propose here to leave the gene encoding this protein in the SAP gene family.

The Sap isoenzymes have a propeptide containing one Lys-Arg Kex2p processing sequence (Julius et al., 1984) immediately preceding the $\mathrm{N}$-terminus of the mature form of the enzyme. YAP3 was cloned based upon its ability to suppress the processing defect of an $S$. cerevisiae kex2 null mutant (Egel-Mitani et al., 1990). It has been shown recently that $C$. albicans kex 2 null mutants continue to secrete active Sap2p (Newport \& Agabian, 1997) but the enzyme was abnormally processed with an additional amino acid at its $\mathrm{N}$-terminus, and was secreted at reduced levels. Although autocatalysis of the enzyme cannot be excluded, processing of Sap2p in C. albicans kex2 null mutants may involve activation by a Yap3p homologue which could be Sap9p. However, the exact role of Sap9p remains to be investigated.

In total, nine $S A P$ genes have now been cloned by low stringency hybridization with $S A P$ gene probes and a consensus oligonucleotide probe designed on the basis of the sequence encoding the $\mathrm{N}$-terminal aspartyl domain of the catalytic site of Sap isoenzymes. All bands A1-A8 identified by Southern blotting of EcoRI-digested genomic DNA of C. albicans and hybridization with both types of probes (Monod et al., 1994) can now be assigned to a specific $S A P$ gene. No other SAP genes were found on cloned EcoRI fragments showing only a slight signal with the oligonucleotide probe. Sequencing of the entire C. albicans genome, which is under way, may reveal other $S A P$-like genes in addition to those described. However, with the cloning methods used previously (Monod et al., 1994) and in this study, the likelihood of finding additional SAP genes in the $C$. albicans genome is rather low.

\section{ACKNOWLEDGEMENTS}

This work was supported by the Swiss National Foundation for Scientific Research, grant 3100-043193.

\section{REFERENCES}

Ash, J., Dominguez, M., Bergeron, J. J. M., Thomas, D. Y. \& Bourbonnais, Y. (1995). The yeast proprotein convertase encoded by YAP3 is a glycophosphatidylinositol-anchored protein that localizes to the plasma membrane. J Biol Chem 270, 20847-20854.

Chambers, S. P., Prior, S. E., Barstow, D. A. \& Milton, N. P. (1988). The pMTL nic ${ }^{-}$-cloning vectors. 1. Improved polylinker region to facilitate the use of sonicated DNA for nucleotide sequencing. Gene 68, 139-149.

Colthurst, D. R., Schauer, 8. S., Hates, M. V. \& Tuite, M. F. (1992). Elongation factor 3 (EF-3) from Candida albicans shows both structural and functional similarity to EF-3 from Saccharomyces cerevisiae. Mol Microbiol 6, 1025-1033.

Crandall, M. \& Edwards, J. E. (1987). Segregation of proteinasenegative mutants from heterozygous Candida albicans. J Gen Microbiol 133, 2817-2824. 
Egel-Mitani, M., Flygenring, H. P. \& Hansen, M. T. (1990). A novel aspartyl protease allowing $K E X 2$-independent $M F \alpha$ propheromone processing in yeast. Yeast 6, 127-137.

Gerber, L. D., Kodukula, K. \& Udenfriend, S. (1992). Phosphatidylinositol glycan (PI-G) anchored membrane proteins. J Biol Chem 267, 12168-12173.

Grossberger, D. (1987). Minipreps of DNA from bacteriophage lambda. Nucleic Acids Res 15, 6737.

von Heijne, G. (1986). A new method for predicting signal sequence cleavage sites. Nucleic Acids Res 14, 4683-4690.

Higgins, D. G. \& Sharp, P. M. (1989). Fast and sensitive multiple sequence alignments on a microcomputer. CABIOS 5, 151-153.

Hube, B., Monod, M., Schofield, A., Brown, A. J. P. \& Gow, N. A. R. (1994). Expression of seven members of the gene family encoding secretory aspartyl proteinases in Candida albicans. Mol Microbiol 14, 87-99.

Hube, B., Sanglard, D., Monod, M., Brown, A. J. P. \& Gow, N. A. R. (1997a). Extracellular proteolytic activity of Candida species. In Host-Fungus Interplay. Proceedings of the 5th Symposium on Topics in Mycology 1995, pp. 109-122. Edited by H. Vanden Bossche, D. A. Stevens \& F. C. Odds. Bethesda, MD: National Foundation for Infectious Diseases.

Hube, B., Sanglard, D., Odds, F. C., Hess, D., Monod, M., Schäfer, W., Brown, A. J. P. \& Gow, N. A. R. (1997b). Disruption of each of the aspartyl proteinase genes $S A P 1, S A P 2$, and $S A P 3$ of Candida albicans attenuates virulence. Infect Immun 65, 3529-3538.

Julius, D., Brake, A., Blair, L., Kunisawa, R. \& Thorner, J. (1984). Isolation of the putative structural gene for the lysine-argininecleaving endopeptidase required for processing of yeast prepro- $\alpha$ factor. Cell 37, 1075-1089.

Monod, M., Togni, G., Hube, B. \& Sanglard, D. (1994). Multiplicity of genes encoding secreted aspartic proteases in Candida species. Mol Microbiol 13, 357-368.

Morrison, C. J., Hurst, S. F., Bragg, S. L., Kuykendall, R. J., Diaz, H., Pohl, J. \& Reiss, E. (1993). Heterogeneity of the purified extracellular aspartyl proteinase from Candida albicans: characterization with monoclonal antibodies and $\mathrm{N}$-terminal amino acid sequence analysis. Infect Immun 61, 2030-2036.
Morrow, B., Srikantha, T. \& Soll, D. R. (1992). Transcription of the gene for a pepsinogen, $P E P 1$, is regulated by white-opaque switching in Candida albicans. Mol Cell Biol 12, 2997-3005.

Morrow, B., Ramsey, H. \& Soll, D. R. (1994). Regulation of phasespecific genes in the more general switching system of Candida albicans strain 3153A. J Med Vet Mycol 32, 287-294.

Newport, G. \& Agabian, N. (1997). KEX2 influences Candida albicans proteinase secretion and hyphal formation. J Biol Chem 272, 28954-28961.

Sambrook, J., Fritsch, E. F. \& Maniatis, T. (1989). Molecular Cloning: a Laboratory Manual, 2nd edn. Cold Spring Harbor, NY: Cold Spring Harbor Laboratory.

Sanglard, D., Hube, B., Monod, M., Odds, F. C. \& Gow, N. A. R. (1997). A triple deletion of the aspartyl proteinase genes SAP4, $S A P 5$, and SAP6 of Candida albicans causes attenuated virulence. Infect Immun 65, 3539-3546.

Soll, D. R. (1992). High-frequency switching in Candida albicans. Clin Microbiol Rev 5, 183-185.

Swoboda, R. K., Bertram, G., Colthurst, D. R., Tuite, M. F., Gow, N. A. R., Gooday, G. W. \& Brown, A. J. P. (1994). Regulation of the gene encoding translation elongation factor 3 during growth and morphogenesis in Candida albicans. Microbiology 140, 2611-2616.

Togni, G., Sanglard, D., Falchetto, R. \& Monod, M. (1991). Isolation and nucleotide sequence of the extracellular acid protease gene (ACP) from the yeast Candida tropicalis. FEBS Lett 286, 181-185.

de Viragh, P. A., Sanglard, D., Togni, G., Falchetto, R. \& Monod, M. (1993). Cloning and sequencing of two Candida parapsilosis genes encoding acid proteases. J Gen Microbiol 139, 335-342.

White, T. C. \& Agabian, N. (1995). Candida albicans secreted aspartyl proteinases: isoenzyme pattern is determined by cell type, and levels are determined by environmental factors. $J$ Bacteriol 177, 5215-5221.

White, T. C., Miyasaki, S. H. \& Agabian, N. (1993). Three distinct secreted aspartyl proteinases in Candida albicans. J Bacteriol 175, 6126-6133.

Received 9 March 1998; revised 8 June 1998; accepted 22 June 1998. 